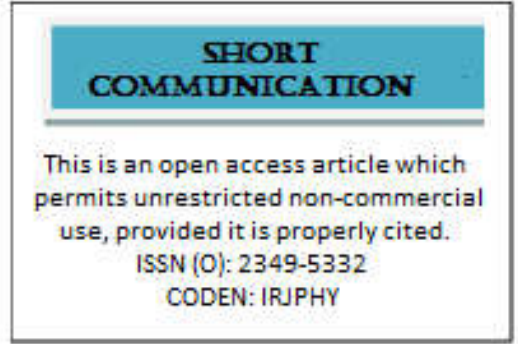

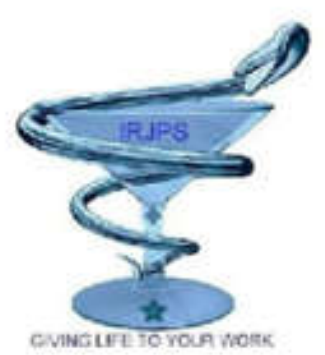

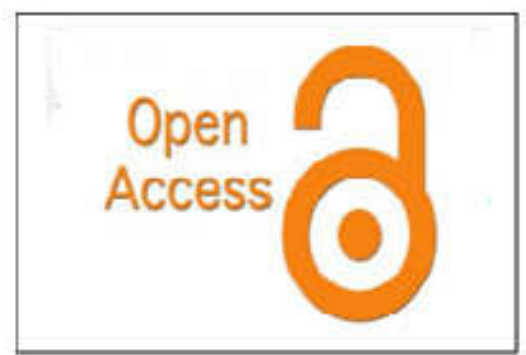

APHANAMIXIS POLYSTACHYA (WALL) PARKER PHARMACOGNOSTIC PROFILE \& MEDICINAL USES

\title{
Apeksha Rawat
}

Sunrise Academy Management Society, Dehradun, Uttarakhand, India,

\begin{abstract}
:
Present abstract highlight a biological activity of a red listed medicinal plant harinhara Aphanamixis polystachya (wall) parker. In the present study the tree of aphanamixis polystachya was investigated for its pharmacognostic parameter, medicinal uses.

Aphanmixis medicinal tree traditionally used for thousand of year in region ayurvedic Ramayana has been investigated. In Himalaya, Uttarakhand, south etc. The plant is enlisted as vulnerable in southern parts of India especially in Karnataka and karalla.
\end{abstract}

Seeds are anathematic, laxative, and refrigerant. Seed oil is used as liniments in muscular.

KEY WORDS: Harinhara, Aphanamixis polystachya (wall) parker, ethanomedicine, ayurveda, unani, pith raj.

\author{
Corresponding Author: Apeksha Rawat \\ Email: rawatapeksha@gmail.com \\ Cell no: +917088835556
}

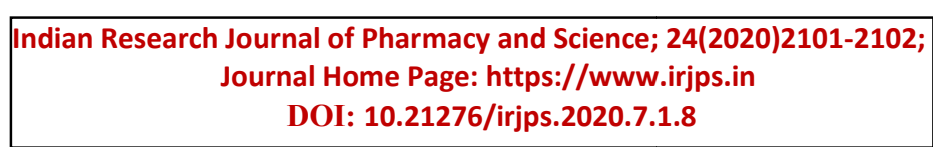


Plant Profile: Aphanamixis polystachya (wall)

parker=amoora; Family meliaceae,

The tree is commonly known as Harihnara, rohitaka.the stem bark commercially known as roheda chhal or rakta rohida.the dried bark powder was subjected to photochemical work. ${ }^{1,2}$

Description: Large canopy tree (up to $25 \mathrm{~m}$ high, rarely to $35 \mathrm{~m}$ ), cylindrical bole or markedly fluted (slightly up to $100 \mathrm{~cm}$ dia.) often crooked or straight (bole up to $15 \mathrm{~m}$ long), buttresses present (buttresses1-4m high), spines absent; aerial roots aerial roots absent; stilt roots absent. ${ }^{1,2}$

Macroscopic features: The bark visual inspection provides the quickest and simplest mean by which to establish identity, purity and quality. Macroscopic identity of a medicinal plant material is based on shape, size, colour, taste, surface characteristic, texture, fracture characteristic and appearance of cut surface (WHO). ${ }^{1,2}$
Microscopic features: In microscopically examination of epidermal trichomes and calcium oxalate are extremely valuable, especially in powdered drug, as the cells are most likely broken except lignified cells. The cells contents such starch granules, calcium oxalate crystals and aleuronic grain etc. starch granules, calcium oxalalate crystals, epidermal trachoma's and lignin are examined carefully synonym (WHO guidelines 1998). ${ }^{1,2}$

Traditional Uses: The bark are acrid, astringent, bitter, digestive, anathematic, depurative, urinary astringent, ophthalmic. ${ }^{1,2}$

\section{REFERENCES:}

1. Natural medicine references manual, Ed 1998, eastern publisher.

2. Department of ayush. A Gateway for information on ayrveda, yoga naturopathy, unani, sidda and Homoeopathy. 